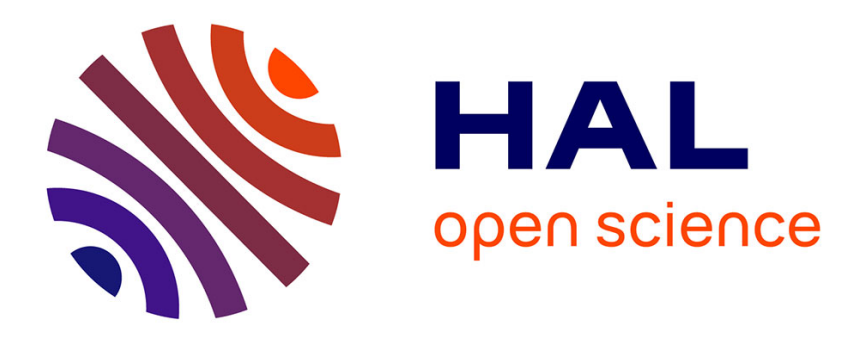

\title{
Conditions of success of a school's self-evaluation : some lessons of an European Experience
}

Denis Meuret, Sophie Morlaix

\section{To cite this version:}

Denis Meuret, Sophie Morlaix. Conditions of success of a school's self-evaluation: some lessons of an European Experience. School Effectiveness and School Improvement, 2003, 14 (1), pp.53-71. 10.1076/sesi.14.1.53.13867 . halshs-00004965

\section{HAL Id: halshs-00004965 https://shs.hal.science/halshs-00004965}

Submitted on 5 Feb 2018

HAL is a multi-disciplinary open access archive for the deposit and dissemination of scientific research documents, whether they are published or not. The documents may come from teaching and research institutions in France or abroad, or from public or private research centers.
L'archive ouverte pluridisciplinaire HAL, est destinée au dépôt et à la diffusion de documents scientifiques de niveau recherche, publiés ou non, émanant des établissements d'enseignement et de recherche français ou étrangers, des laboratoires publics ou privés. 
Conditions of success of a self evaluation

Conditions of success of a school's self-evaluation:

Some lessons of an European Experience

Denis Meuret and Sophie Morlaix, Université de Bourgogne, IREDU

Article published in the journal "School Effectiveness and School Improvement", 14 (1), 2003

\begin{abstract}
This study uses data from an European Project on school self-evaluation. A hundred and one schools experimented with self-evaluation and reported on what they did and what were the outcomes of the process. It is therefore possible to look at which characteristics of the process are associated with a positive appreciation of its effects. This analysis is conducted by confronting 2 general models of self-evaluation, named here the "technical" model and the "participating” models. The 2 models are presented, then their ability to explain the success of a process of self-evaluation is compared. The explaining power of both models appear to be rather close, a result which makes it relevant to look at their optimal combination.
\end{abstract}




\section{INTRODUCTION}

School self-evaluation is commonly seen as a process of school evaluation which is performed by at least part of the school's stakeholders- management, staff, pupils and parents. It is opposed to "external evaluation” where the judgement on the school is delivered by external agents. Defined this way, school self-evaluation is on the educational agenda in all European countries, and in some of them has been for a long time ${ }^{1}$. It is perceived as a logical consequence of the greatest autonomy enjoyed by schools (OECD, 1998) and as one way to enhance the responsiveness of schools to the needs of their intake, as well as to allow them to improve.

However, school self-evaluation is not common practice. In France, the Ministry advises schools to develop a "culture of evaluation" and sends them indicators to assist them in that process, but these indicators are used at best by $5 \%$ of the schools. Trendy development plans are for them a more sure way to attract extra resources than to give evidence of their effectiveness. Local administrators confess they lack the time and skills for any kind of evaluation (Lepage, 2000), with the effect that there are no external incentives for selfevaluation. In England, self-evaluation matters less for schools than external inspection does, although it has been shown that the latter is not free from bias and shortcomings which are sometimes reproached to the self-evaluation (Fitz-Gibbon, 1996).

Moreover, school self-evaluation is not very popular among school staff. For instance, in the European Project where our data come from, 101 secondary European schools were asked their attitude towards external versus self-evaluation at the beginning of the Project. They were a little more inclined to appreciate self-evaluation, but only a third declared that it was "liked by most staff” (Macbeath, Meuret, Schratz and Jakobsen,1999). Even then, these schools were supposed to be among those in their countries with a more positive attitude towards self-evaluation.

We have some (limited, for the time being) evidence that self-evaluation may enhance school effectiveness and improvement. Theoretical arguments are numerous and will be presented

\footnotetext{
${ }^{1}$ In France, first attempts were made in 1975 (see Meuret,1987), in England, around the same date (see Simmons,1988).
} 
hereafter. On a more empirical basis, Sammons, Hillman, and Mortimore (1995) include “evaluating school performance” among the key characteristics of effective schools.

This configuration - in short, evaluation is likely to be useful, but it is more praised by policymakers than it is liked and really used by the schools - makes it relevant to study the factors that are associated with the success of a school self-evaluation ${ }^{2}$. As far as we know, this has not yet been studied on an empirical basis. To some extent, the European project “Evaluating quality in school education” (MacBeath et al., 1999) provides us with data that will allow to make such a study.

In this study, we will confront 2 models of self-evaluation. Looking more closely at it, the agents excluded by the notion of "self" evaluation are not really "external” agents but more specifically “authorities. For instance, an external "Critical friend” may be hired by a school to help in a process of self-evaluation (Macbeath,1999). However, the exclusion of authorities does not rule out that in some self-evaluations, the judgement is delivered by the school on itself, but partly on the basis of criteria advised, or even of data provided, by authorities. This ambiguity results in the existence of two main streams among the school self-evaluation patterns, which are often seen as opposite regarding their organisational and also political meaning.

We will present further these model in more details. Let us just say now that the "Technical model” rests on quantitative indicators which are often imposed or strongly suggested by the authorities, while the "Participating model" (PM) rests on the school stakeholders judgements. They have been presented as the "English model" opposed to the "Alternative model” (Saunders,1999). We will, however, not use these labels, because, from a French point of view, Great Britain would be rather the Promised Land for the "Alternative model”, which has inspired a lot of research and practices in this country (e.g., Macbeath, 1999), while the so called "English model" has a quasi-monopoly of school self-evaluation in France, one of the authors (DM) having to confess some small responsibility in this situation.

\footnotetext{
2 This article will address only internal factors of success, that is factors related to the process of school selfevaluation, although it is obvious that external factors also play an important role. Among the external factors are, for instance, the "culture" of the educational systems or its regulation methods: More school autonomy is likely to favour self-evaluation, as is the existence of some rewards for the most effective, or the most equitable, schools (Du \& Heistadt., 1999). But the small number of schools per country in our sample does not allow for an investigation of these factors.
} 
Our aim in this article is to compare the relevance of the 2 models through a simple test: Do schools which implement one model declare more often than schools which implement the other model that the evaluation was successful? As schools did not actually implement pure models the test becomes: Does a set of variables representative of one model explain better than a set of variables illustrative of the other model the degree to which schools declare that the evaluation was successful?

Four possibilities do exist : TM is far more able than PM to explain the success ; PM is far more able than TM to explain the success ; There is no strong difference between the abilities of the two models to explain the success ; In turn, two configurations could explain the last situation: either the success of self-evaluation is better guaranteed by some relevant combination of the two models than by each model alone, or each model suits an equal number of schools.

We will first explain where our data come from, then how we operationalise the two models with these data, then present our method and results.

\section{DATA}

\section{Source of Data}

Our data come from the pilot project "Evaluating quality in school education”, monitored by The European Commission (DG 22/A1). More detailed information on this project may be found in its final report (Macbeath et al., 1999), as well as in Macbeath, Schratz, Meuret and Jakobsen (2000). The project involved 101 secondary schools in 18 European countries, the number of schools in each country having been selected roughly in proportion to country size. For the purpose of international consistency, the focus was on general education.

Schools were selected by a National Committee which reviewed school eligibility on the basis of an "application profile” submitted by the school. Therefore, in theory, schools volunteered. The most important criterion for participation was whether schools were interested in or committed to evaluation. In this sense, participating schools were selected by virtue of their positive attitude to self-evaluation. However, in some countries, even the schools with a wider experience of self-evaluation and keener on it, had a rather weak experience as well as inclination.

Owing to the selection process, our sample is far from representative of European secondary schools. Therefore, what we present is only an analysis of the relations between some 
characteristics of the evaluation process and its estimated success among some schools which were among the more inclined or the less reluctant to self-evaluation in their respective countries.

The selected schools evaluated themselves during the school year 1997-1998, according to the following procedure :

1. Set up a school steering group of 6-8 persons, preferably involving all stakeholders (teaching and non-teaching staff, pupils, parents, management), which had to initiate and monitor the process.

2. Answer a first questionnaire on the school initial attitude to self-evaluation.

3. Hire a Critical Friend.

4. Produce a general diagnosis, through a process of several meetings involving representatives of all categories of stakeholders. An instrument called the "self-evaluation profile" (SEP) helped to focus this discussion on 12 area of the school: three on outcomes (Academic achievement, Personal and social development, Pupils destinations), three on processes at the classroom level (Time as a resource for learning, Quality of learning and teaching, Support for learning difficulties), three on processes at the school level (School as a learning place, School as a social place, School as a professional place) and three on the relations with the Environment (School and home, School and community, School and work). This discussion helped to choose 4 or 5 areas for further investigation.

5. Proceed to these further investigations, using any method or instrument the school thought to be relevant. A “Practical guide to self-evaluation” provided schools with insights of different available methods, both quantitative (indicators, questionnaires, achievement tests) and qualitative (Focus groups, Photo-evaluation, Force field, etc.). This was the core of the self-evaluation process.

6. From this diagnosis, elaborate (and, for the more advanced schools, implement) some strategies or actions in order to help the school to improve.

7. The school steering group had to answer a final questionnaire which was an evaluation of the process: Evaluation of the role of the steering group, of the Critical Friend, of the SEP, Number of further investigations completed in the diverse area, a description of two further investigations; an evaluation of the impact of the project on the school, of the satisfaction of the stakeholders with the project, and of the attitude of the school to selfevaluation after the project. 
The nature of this framework has an important consequence for this study: The processes which will be compared are not the ones that narrow-minded supporters of each model would have implemented, but more realistic ones, which were implemented by schools more or less close to the two models inside a general framework of mixed inspiration.

\section{Data on the Success of Self-evaluation}

We assess the success of the self-evaluation process - that is the dependant variable - through two dimensions, both from the final questionnaire.

The first is the estimated impact on effectiveness and ability to improve, as the mean score of the answers to the last two questions in Table 1.

\begin{tabular}{|l|c|c|}
\hline \multicolumn{3}{|c|}{ Table 1 Impact of the Self-evaluation Process on the School, } \\
According to the Steering Groups \\
\hline The project has... & Mean & $\begin{array}{c}\text { Standard } \\
\text { deviation }\end{array}$ \\
\hline$\ldots$ helped to create a better climate in the school & 3.5 & 1.3 \\
\hline ... enhanced pupil's commitment to learning & 2.7 & 1.3 \\
\hline ... strengthened the commitment of staff for the benefit of all & 3.5 & 1.3 \\
\hline ... led to other positive change for the pupils & 3.5 & 1.3 \\
\hline ... led to other positive change for staff & 3.5 & 1.3 \\
\hline ....improved our knowledge and understanding of the school & 4.7 & 1.0 \\
\hline ... enhanced the school's ability to improve & 4.5 & 1.2 \\
\hline ... enhanced the effectiveness of the school & 3.7 & 1.4 \\
\hline N = 101 schools & & \\
\hline
\end{tabular}

We use the mean score of the two items because the PM proponents are generally more interested in school "improvement” and the TM proponents in school "effectiveness".

The second is the Final attitude to self-evaluation. It is a relevant criterion since it commands the likeliness of self-evaluation to become a permanent feature of the school life. We define it as the mean score of four questions: self-evaluation tells us a lot, improves teaching, improves management, is cost effective. The mean for the 101 schools for these criteria on a 1 (low) to 6 (high) scale were respectively: 5,1; 4,4; 4,6; 4,4. 
These data reflect the opinions of a group of well-informed persons - the school steering group - on these topics, just at the end of the process. These persons were most often very involved in the process and may therefore overestimate the success, but, since we try here to explain differences among schools, this is a problem only if this bias is different from one school to the other.

Our independent variables required the operationalization of the Technical and Participative models (TM and PM) They are presented in the following chapter.

\section{THE TECHNICAL AND THE PARTICIPATING MODELS (TM and PM)}

Advocates of both models of school self-evaluation share the idea that to have a look at what occurs in the school in a rather organised manner will help improve its operation. As obvious as it may seem, this is irrelevant in several contexts; for instance, when the school level has only limited influence on the classroom level, or if the school is organised through "synoptic planning” (Scheerens, 1997). In that last case, planning is so comprehensive (objectives are deduced from goals, curriculum and teaching methods are deduced from objectives, teaching methods are monitored) that only pupils assessment is required. Self-evaluation is neither relevant if a school is defined as "Professional Bureaucracy" (Mintzberg,1979): if standardisation and similar training of staff are the only means of coordination of highly autonomous professionals, no school self-evaluation is required.

However, from that common point, TM and PM diverge, mainly because evaluation is outcomes-driven in the former while it is process-driven in the latter.

The TM may be seen as a part of "retroactive planning", that is something less demanding that "synoptic planning" : planning has a more incremental orientation, goals get the function of standards for interpreting evaluative information, and the discrepancy between actual achievement and expectations creates the dynamics that could eventually lead to more effectiveness (Scheerens, 1997).

But the popularity of TM among educational authorities comes mainly from the fact that it may be seen as a rather soft way to deal with the shortcomings that Public choice theory (Niskanen, 1971), sociology of organizations (Bidwell, 1965) or Minzberg (1979) himself see as inherent to the bureaucratic aspect of schools. For instance, the existence of outcomes indicators will limit the risk of goals displacements or of disengagement from actors. If these 
indicators are "value added" ones, they allow to reduce the uncertainty on standards which comes from the diversity of school intakes. So the asymmetry of information between "agent" and "principal” is reduced (Milgrom \& Roberts, 1992). Similarly, a discussion among teachers to interpret outcomes indicators may be seen as a way to lessen the tension that Bidwell sees between the professional and the bureaucratic aspect of the schools, or as a way to allow the manager of the Professional Bureaucracy to overcome the resistance of professionals to coordination.

In schools that implement a more "TM" like process of self-evaluation:

- The role of the management of the school will be stronger than in other schools. For instance, Emin (1996, p. 240) writes : “IPES (the French system of indicators for secondary schools) is about school self-evaluation. It is a tool for the Schoolhead and his team”.

- $\quad$ Special attention will be given to the ability of data or investigations to allow for a valid diagnosis of the school functioning. As "instrumentalist, action oriented, rationalistic and managerial” (Saunders, 1999,p 414), this model highly values the ability of the process to result in an accurate picture of the school, necessary to take relevant decisions.

- Process matters in the TM only as far as it explains outcomes, and, moreover, the link between process and outcomes is sometimes doubtful, therefore, the outcomes will be scrutinised more than the process of schooling.

Therefore our model is composed of the following variables :

- Involvement of the Critical friend with the Management of the school .

- Impact of the Critical friend on the Management of the school .

- $\quad$ Adequate data were available to support views for completing the Self-evaluation Profile (SEP).

- $\quad$ The diagnosis carried on through the SEP was estimated to be reliable.

- The SEP process resulted in a careful choice of area for further examination.

- A higher proportion of further examinations than in the other schools dealt with outcomes (i.e. academic achievement, personal and social development, pupils destinations) as opposed to process or context. ${ }^{3}$

\footnotetext{
${ }^{3}$ Our file did not allow us to disentangle the three outcomes, therefore we were hindered to define the TM as interested only in academic achievement. However, it may be argued that TM does not have to be interested only in this kind of achievement. Proponents of the TM (e.g. OFSTED) or school effectiveness researchers (e.g.Grisay,1997; Meuret \& Marivain, 1997; Knuver \& Brandsma,1993; Opdenakker and Van Damme, 2000) sometimes include non academic outcomes in their investigations.
} 
- At the end of the project, self-evaluation was deemed to improve the management of the school.

The PM leans on the critics which have been levelled to retroactive planning, that is it does not take into account of the ambiguity of the goals of schooling ${ }^{4}$, and the difficulty to determine causality of observed events (Scheerens,1997). For both reasons, it is argued, evaluation (and schools) cannot be outcomes driven, what counts is the process. The PM is linked with theories more related with psychology and politics than with economy. Some of them are presented in Fetler (1994). The human resource frame deems the central task of managers to be harmonising the needs of schools with the needs of people who work in them, which may signify that they must arrange conditions so that the employees self interest coincides with the organisation's interest. The political frame views schools as arenas where coalitions compete for limited or scarce resources. Decisions are the product of bargaining and negotiation. Goals are frequently a product of negotiation among those people who have power. In such frames, the "official” goals of the school are only benchmarks among others, and the school self-evaluation looks for the fluidity and harmony of the process, and only indirectly for effectiveness.

Gather-Thurler (1994, p. 205) refers the participative model to the "socio-constructivist" theory and to "symbolic interactionism". Evaluation has to "favour the process by which teachers, through experience and interactions, take over their profession” (our translation). It has to help the process by which teachers “construct their own representations and meanings”. This may be close to cultural theory, according to which the main point is how people assign meaning and interpret their experience (Fetler,1994). All this suits the tendency of the participating model to deal more with people's judgements than with hard facts.

Therefore, participation of all stakeholders in the process of self-evaluation is important for theoretical reasons: the school is conceived more as a network of relations among individuals than as a "productive" organisation. In a sense, the social process of self-evaluation is more important than the diagnosis it produces: it improves relations and enhances commitment ${ }^{5}$.

Participation is also important for practical reasons: PM investigations are more grounded on discussions among stakeholders than on statistics, and the more participants there are in these

\footnotetext{
${ }^{4}$ This means also that, the less ambiguous the goals are, the more TM is likely to succeed. Its progress in UK and the US is related to the recent and strong orientation on "basics" and to the use of standards in these countries.

${ }^{5}$ The Finish report of the European Project wrote that : “" In the course of the project, the view grew stronger that (..) the process of school self evaluation is even more important than the results that it produces » (p5).
} 
discussions, the more likely this results in improved relations among all stakeholders, in a mobilized school, and in improvement.

Therefore, our model is composed of variables which deal with the quantity and the quality of relations among all categories of stakeholders during the process of self-evaluation.

There were 24 variables of this kind in the questionnaire, too great a number to be used in our analysis, given the limited number of schools (no more than101). Therefore we calculated the correlation between these variables, and aggregated them in six variables :

- $\quad$ The impact of the Critical friend with the parents and pupils.

- The School steering group was rated as involving most stakeholders and as being successful in motivating people.

- The critical friend was said to be a good listener, to go on well with teachers, to communicate ideas well.

- $\quad$ The participation of pupils and parents was said to be strong.

- SEP Participating: In the process of completing the SEP, enough people were involved, discussions were thorough and relations among the stakeholders improved.

- A higher proportion of further examinations than in the other schools dealt with the school process, as opposed to the three other possible area ${ }^{6}$.

\section{TREATMENTS AND RESULTS}

\section{Treatments}

We computed simple multilinear regressions. Instead we should have used ordered polychotomous models, since our variables are discrete and hierarchical ones (scores on a 6 points scale). However, we were prevented to do it, because of the small number of individuals in our sample: 101, and 70 for the variables OUTCOMES and PROCESS, which reduced the $\mathrm{N}$ to about 70 schools in the analysis where we used these variables.

Precise data on the student body (social composition or academic achievement) in the schools were not available, which prevented us from exploring to what extent the following results are sensitive to this variable.

\footnotetext{
${ }^{6}$ Examinations of the process at the classroom level, were considered to be relevant for both models and therefore were ignored. We are aware that most specialists of school evaluation do not advocate for the purest form of these models. . For instance, Saunders (1999), who advocates what we call "participating model" stresses that "high quality statistical information is crucial to identifying underachievement" (p.418), while
} 


\section{Results}

We will present the conditions for a strong impact on the effectiveness and improvement of the school, then on its final attitude to self-evaluation.

Conditions for a Strong Impact on the School Effectiveness and Ability to Improve

Table 2. Conditions for a Strong Impact on the School Effectiveness and Ability to Improve (Technical Model)

\begin{tabular}{|c|c|c|}
\hline & $\begin{array}{l}\text { Estimate (Standard } \\
\text { error) }\end{array}$ & Student's T \\
\hline Intercept & $7.23(6.0)$ & 1.20 \\
\hline $\begin{array}{l}\text { Involvement of the Critical Friend (CF) with the } \\
\text { Management of the school }\end{array}$ & $1.17(2.9)$ & 0.41 \\
\hline Impact of the CF on the Management of the school & $-0.34(0.5)$ & -0.53 \\
\hline SEP: adequate data were available & $1.60(0.8)$ & $2.04^{* *}$ \\
\hline SEP : allowed for an accurate diagnosis & $0.22(1.02)$ & 0.21 \\
\hline $\begin{array}{l}\text { SEP: resulted in an easy choice of area for further } \\
\text { examination }\end{array}$ & $0.10(0.8)$ & 0.11 \\
\hline $\begin{array}{l}\text { Outcomes were a frequent focus of further } \\
\text { examinations }\end{array}$ & $2.14(0.81)$ & $2.63 * * *$ \\
\hline $\begin{array}{l}\text { Self-evaluation is thought to improve the management } \\
\text { of the school }\end{array}$ & $2.20(0.88)$ & $2.52 * *$ \\
\hline
\end{tabular}

Table 3. Conditions for a Strong Impact on the School Effectiveness and Ability to Improve (Participating Model)

\begin{tabular}{|l|c|c|}
\hline & $\begin{array}{c}\text { Estimate (Standard } \\
\text { error) }\end{array}$ & Student‘s T \\
\hline Intercept & $13.96(6.9)$ & $2.01^{* *}$ \\
\hline
\end{tabular}




\begin{tabular}{|l|c|c|}
\hline Impact of the CF on the pupils and the parents & $-0.19(0.2)$ & -0.79 \\
\hline School Steering Group participative and motivating & $1.14(0.4)$ & $2.62^{* * *}$ \\
\hline The CF was a good listener,... & $-0.45(0.4)$ & -1.20 \\
\hline Strong participation of pupils and parents & $0.29(0.3)$ & 1.00 \\
\hline SEP participative & $0.63(0.4)$ & $1.68^{*}$ \\
\hline Process was a frequent focus of further examinations & $-0.47(0.4)$ & -1.14 \\
\hline Self-evaluation is thought to involve everyone & $0.48(0.6)$ & 0.82 \\
\hline $\mathrm{N}=77 ; \mathrm{R}^{2}=31 \%$ & & \\
\hline
\end{tabular}

As shown in tables 2 and 3, the two models explain roughly the same part of variance, although a fair comparison is biased, in favour of PM, by the difference in the two $\mathrm{N}$ and although the strong and significative value of the intercept in the PM shows that the variables of the model miss an important one, which is therefore included in the intercept.

The equivalence of the two models is confirmed in another way. Schools had to present two of their "further examinations", indicating the methods used and assessing the quality of the investigation. We classified the methods in five categories : Portfolios, Discussions, Observations - which are closer of the PM-, Questionnaires, Achievement tests and others which are closer to the TM. We looked for some correlation between the methods used and first, the judgement on the quality of the examination and, second, the impact of the process on the schools' effectiveness and ability to improve. No significative correlation was found for any of the five categories. This may signify that, in itself, no method is preferable, that the effectiveness of the examination depends more on the relevance of the area which is examined, on how well the method is used, and on the quality of the discussion on its results. The equivalent ability of the two models may be caused either by an equivalent number of schools favouring one model over the other, or by the fact that some items of both models are important.

This last possibility has been tested by a model built with all the variables of PM and TM which appeared to have a significative effect on the estimated impact on Effectiveness and Improvement. Results appear in Table 4.

Table 4 Conditions for a Strong Impact on the School Effectiveness and Ability to Improve (Integrated model) 


\begin{tabular}{|l|c|c|}
\hline & error) & \\
\hline Intercept & $2.68(4.3)$ & 0.63 \\
\hline SEP participative & $0.71(0.4)$ & $1.94^{*}$ \\
\hline School Steering Group participative and motivating & $0.61(0.4)$ & $1.74^{*}$ \\
\hline Outcomes were a frequent focus of further evaluations & $1.43(0.8)$ & $1.82^{*}$ \\
\hline SEP: adequate data were available & $0.17(0.7)$ & O.24 \\
\hline $\begin{array}{l}\text { Self-evaluation is thought to improve the management } \\
\text { of the school }\end{array}$ & $1.74(0.7)$ & $2.43^{* *}$ \\
\hline $\mathrm{N}=77 ; \mathrm{R}^{2}=37 \%$ & & \\
\hline
\end{tabular}

Clearly, the integrated model better explains the variance of the dependent variable than each model separately ( $\mathrm{R}^{2}=37$ instead of 29 or 31 ), although the gap is not very great. This does not exclude that some schools could be more receptive to PM while some others would be more receptive to TM, but the most frequent case - the one we would advise without any further information on the school- seems to be that a process which borrows some characteristics of both models is the most likely to succeed.

A participating and active Steering Group, as well as a Self-evaluation profile completed through thorough discussions involving most stakeholders, as well as investigations on outcomes, with a good impact on the Management of the school : these seem to be the clearest conditions for the process to be judged as having a good effect on school effectiveness and improvement.

\section{Conditions of a Positive Attitude to Self-evaluation}

A first model was designed to assess more rigorously the main conclusion of the "conditional analysis” in the final report of the Project (Macbeath et al., 1999): The main determinant for a positive attitude to self-evaluation was neither strong participation, nor even a high satisfaction of the stakeholders, nor the initial attitude of staff towards self-evaluation, but the judgement on the impact of the process on school effectiveness and ability to improve. Table 5 confirms this statement. This tends to indicate a rather "professional" attitude among the school staff and stakeholders, while a strong influence of the initial judgement, for instance, would have meant a more ideological orientation.

Table 5 Conditions for a Positive Attitude to Self-Evaluation at the End of the Project 


\begin{tabular}{|l|c|c|}
\hline & $\begin{array}{c}\text { Estimate (Standard } \\
\text { error) }\end{array}$ & Student 's T \\
\hline Intercept & $10.9(2.1)$ & $5.21^{* * *}$ \\
\hline $\begin{array}{l}\text { Impact of the process on school effectiveness and } \\
\text { ability to improve }\end{array}$ & $0.20(0.0)$ & $4.48^{* * *}$ \\
\hline Participation of all stakeholders & $0.40(0.4)$ & 1.04 \\
\hline Satisfaction of all stakeholders & $-0.20(0.5)$ & -0.38 \\
\hline Initial judgement on "tells us a lot” & $0.32(0.4)$ & 0.73 \\
\hline Initial judgement on “improves teaching” & $-0.11(0.4)$ & $-0.22(0.29)$ \\
\hline Initial judgement on “improves management” & $-0.05(0.29)$ & -0.19 \\
\hline Initial judgement on “cost effectiveness” & & \\
\hline $\mathrm{N}=67 \mathrm{R}^{2}=35 \%$ & & \\
\hline
\end{tabular}

The former analyses have shown that both models were as likely to explain the impact on effectiveness and improvement. However, the results in Table 5 do not prevent us to study if one model explain better than the other a positive attitude to self-evaluation.

A first investigation may be done by testing if a positive attitude towards self-evaluation comes more from the estimated impact on the improvement of the knowledge of the school and on its effectiveness (which would be in favour of the TM) than from the estimated impact on the school climate and the school ability to improve (which would be in favour of the PM). Table 6 shows that both models explain roughly the same part of variance. However, the impact on the knowledge of the school appears to have a stronger effect than the impact on the school climate, perhaps because its estimation by the stakeholders is more reliable.

Table 6 Conditions for a Positive Attitude to Self-Evaluation at the End of the Project (TM vs PM)

\begin{tabular}{|c|c|c|}
\hline & $\begin{array}{c}\text { Estimate (Standard } \\
\text { error) }\end{array}$ & Student's T \\
\hline
\end{tabular}




\begin{tabular}{|l|c|c|}
\hline Technical model & \multicolumn{1}{|l|}{} \\
\hline Intercept & $12.25(1.3)$ & $9.14^{* * *}$ \\
\hline Impact on the effectiveness & $0.81(0.21)$ & $3.80^{* * *}$ \\
\hline Impact on the knowledge of the school & $0.66(0.30)$ & $2.2 * *$ \\
\hline $\mathrm{N}=101 ; \mathrm{R}^{2}=25 \%$ & & \\
\hline Participative model & $13.22(1.04)$ & $12.59^{* * *}$ \\
\hline Intercept & $0.81(0.29)$ & $2.74 * * *$ \\
\hline Impact on the ability to improve & $0.43(0.28)$ & 1.52 \\
\hline Impact on the school climate & & \\
\hline $\mathrm{N}=101 ; \mathrm{R}^{2}=21 \%$ & & \\
\hline
\end{tabular}

The second investigation (Tables 7 and 8) consisted of directly applying the TM and the PM to the measure of the final attitude, with the impact on the knowledge of the school and on its effectiveness added to the independent variables of the TM, and the impact on the climate and on the improvement being added to the independent variables of the PM. Inversely, in both cases the two variables of the TM and of the PM which came from the question on the attitudes (Self-evaluation is thought to improve management, and to involve everyone) were omitted since they are part of the dependent variable in these models.

\begin{tabular}{|c|c|c|}
\hline \multicolumn{3}{|l|}{ (Technical Model) } \\
\hline & $\begin{array}{l}\text { Estimate (Standard } \\
\text { error) }\end{array}$ & Student 's T \\
\hline Intercept & $12.28(2.4)$ & $5.05 * * *$ \\
\hline Strong impact on effectiveness & $0.75(0.3)$ & $2.7 * * *$ \\
\hline Strong impact on the knowledge of the school & $0.41(0.4)$ & 1.1 \\
\hline $\begin{array}{l}\text { Involvement of the Critical Friend with the } \\
\text { Management of the school }\end{array}$ & $-0.67(1.1)$ & -0.58 \\
\hline $\begin{array}{l}\text { Impact of the Critical Friend on the Management of } \\
\text { the school }\end{array}$ & $0.02(0.2)$ & -0.12 \\
\hline SEP: adequate data were available & $-0.25(0.3)$ & -0.79 \\
\hline SEP : allowed for an accurate diagnosis & $0.07(0.4)$ & 0.18 \\
\hline SEP : resulted to an easy choice of area for further & $0.50(0.4)$ & 1.41 \\
\hline
\end{tabular}




\begin{tabular}{|l|l|l|}
\hline examination & & \\
\hline Outcomes were a frequent focus of further evaluations & $0.28(0.3)$ & 0.41 \\
\hline $\mathrm{N}=64 \mathrm{R}^{2}=27 \%$ & \\
\hline
\end{tabular}

\begin{tabular}{|c|c|c|}
\hline \multicolumn{3}{|c|}{$\begin{array}{l}\text { Table } 8 \text { Conditions of a Strong Impact on a Positive Attitude to Self-evaluation } \\
\qquad \text { (Participating Model) }\end{array}$} \\
\hline & \begin{tabular}{|l|} 
Estimate $\quad$ (Standard \\
error)
\end{tabular} & Student's T \\
\hline Intercept & $7.60(2.9)$ & $2.60 * *$ \\
\hline Strong impact on the school ability to improve & $0.75(0.3)$ & $2.19 * *$ \\
\hline Strong impact on the school climate & $0.14(0.4)$ & 0.37 \\
\hline Impact of the CF on the pupils and the parents & $-0.08(0.1)$ & -0.81 \\
\hline School Steering Group participative and motivating & $0.09(0.2)$ & 0.50 \\
\hline The CF is a good listener... & $0.20(0.2)$ & 1.28 \\
\hline Strong participation of pupils and parents & $-0.02(0.1)$ & -0.19 \\
\hline SEP participating & $0.23(0.1)$ & 1.60 \\
\hline $\begin{array}{l}\text { School process was a frequent focus of further } \\
\text { evaluations }\end{array}$ & $-0.00(0.2)$ & -0.02 \\
\hline $\mathrm{N}=77 ; \mathrm{R}^{2}=29 \%$ & & \\
\hline
\end{tabular}

Again, there is no true difference between the explaining power of the two models, and the impact on the effectiveness of the school and its ability to improve are the strongest predictors of a positive attitude to self-evaluation.

\section{DISCUSSION}

The bulk of our results is summed up in Figure 1 :

Fig.1 : Conditions of deemed success of a self-evaluation

\begin{tabular}{|l|l|}
\hline Assessment of outcomes & $\begin{array}{l}\text { Impact on the } \\
\text { knowledge and on the } \\
\text { effectiveness of the } \\
\text { school }\end{array}$ \\
\hline $\begin{array}{l}\text { Improvement of the } \\
\text { management of the school }\end{array}$
\end{tabular}




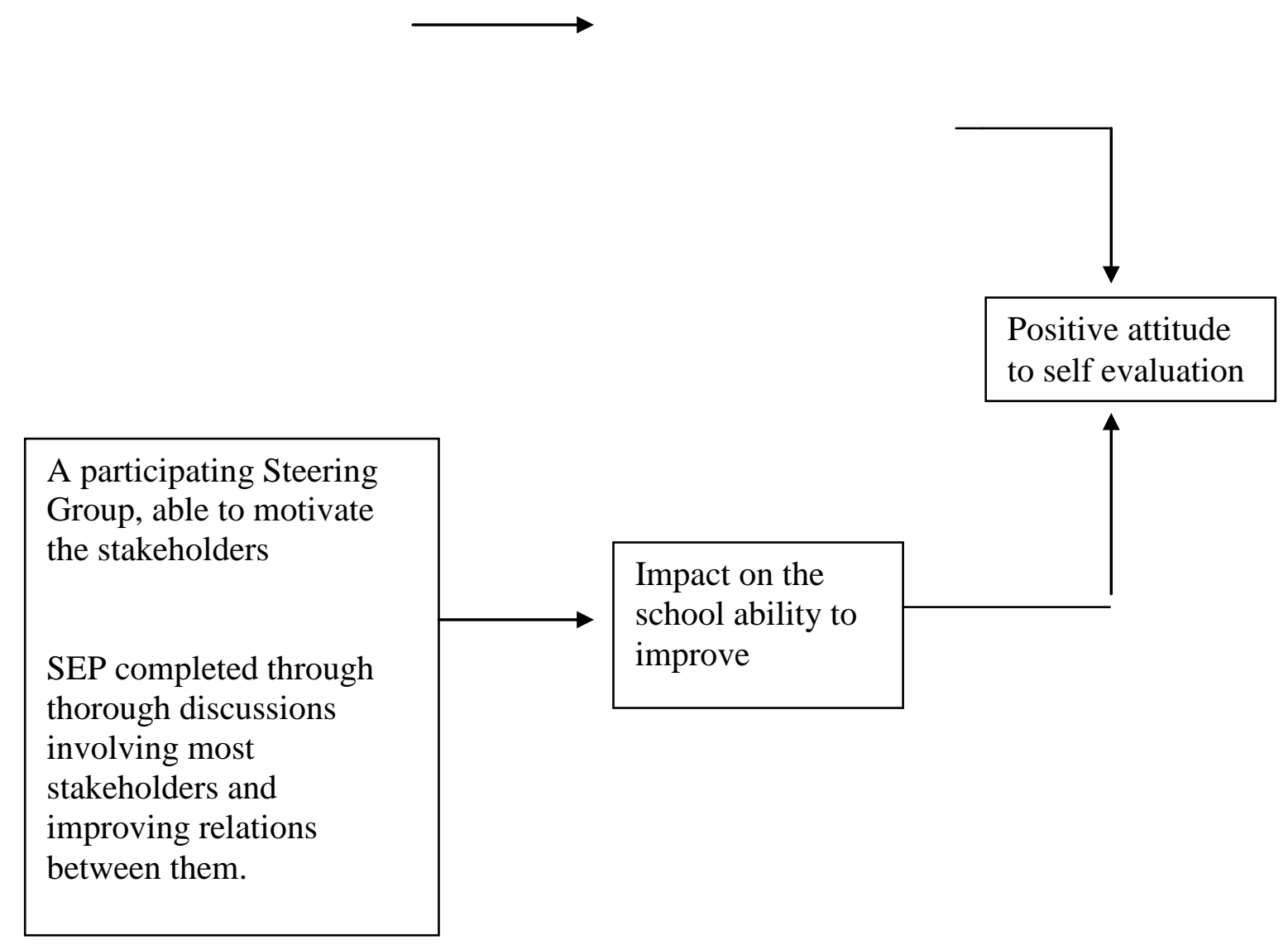

Figure 1 stresses the importance of the initial phase of the evaluation process, that is the composition of the steering group and the way the general diagnosis is established in order to decide what are the area which need more thorough investigation, a diagnosis which was completed in the European Project through the SEP procedure. This shows that methods or indicators, which experts often exclusively focus on, are only the tools of a process of which the general quality - relevance of investigated area, true improvement of the knowledge of the school, likeliness that the conclusion will be used for improvement, thoroughness of discussions, etc. - leads to success.

Surprising is the weakness of the influence of the Critical Friend, whose role was indeed highly appreciated by stakeholders (Macbeath et al., 1999). A reason could be that most Critical Friends had the same kind of influence on schools, and therefore do not explain differences among them. However, standard variations of the scores of the Critical Friend were not so much weaker than those of other scores. The reason is therefore probably that our analysis is only able to account for the most direct influences on the success while the one of the Critical Friend is, by its nature, indirect. Indeed, the results here provide insights into what the Critical Friend should pay attention to: The functioning of the steering group and of the SEP process. 
The Technical and Participating models are on a par. Their explaining power is about the same, and is not very high, at least with the imperfect and insufficient variables which were at our disposal. The harsh debate among experts seems to be of limited relevance for the stakeholders.

This equality is, in some sense, to the advantage of the Technical Model, since one of the main arguments of its adversaries is that it hurts the stakeholders culture and morale, while our criterion of success here was the opinion of these stakeholders. However, it may be argued that what is assessed here is a technical orientation inside a process which, in its basic conception, was a participating one: the European documents insisted on the participation of all stakeholders in all phases of the process.

More interesting is to look at the meaning of the combination of both models which seems to work according to Figure1.

What seems to be disproved in the discourse against the TM is the idea that any measurement of outcomes is an attack against the liberty and dignity of the staff and is so far of the true functioning of schools that it will be immediately sanctioned by rejection. In its more extreme form, the participating model conceives the effects of schooling to be so diverse, so specific to each pupil, so elusive, that outcomes cannot be a priori defined and that schools have to be only driven by a discussion among professionals about the process. This conception is not endorsed by our results.

What seems to be disproved in some discourse in favour of the TM, is the conception of a school as a tool in the hands of the Management, and evaluation as a simple gathering of data in order to allow the Management to take enlightened decisions. Indeed, our results show that the process of evaluation has to be a participating, and not a technical, one, not only at the operational level, but in its conception and monitoring. Indeed, data and indicators appear to be useful, but they have to be "user friendly", in order to be used in discussions among the stakeholders, and not by school level technocrats.

Acknowledgements : We are in profound debt to Lars Bo Jakobsen, John MacBeath and Michael Schratz, who were at the heart of the European Project "Evaluating Quality in School Education, as well as to all those, in the European Commission, in the National 
Committees, and in the schools, who make this Project such a pleasant, rewarding and useful experience. We thank two anonymous referees for their remarks, and Thierry Chevaillier for his help. We are of course the only ones responsible for the analysis presented in this article.

\section{REFERENCES}

Bidwell, C.E. (1965). The school as a formal organization, in J.G. March (Ed.)Handbook of organizations, chap. 23, Chicago :Rand Mac Nally and Co.

Du, Y. \& Heistad, D. (1999). School performance accountability in Minneapolis public schools. Paper presented at the Annual Meeting of the American Educational Research Association, Montreal.

Emin, J.C. (1996). Les indicateurs pour le pilotage des établissements scolaires du second degré, [Indicators for the monitoring of secondary schools] in J. Vogler, Ed. L'évaluation, pp. 239-246, Paris : Hachette,

Fetler, M. (1994). Carrot or stick? How do performance report work? Evaluation and Policy Analysis Archives, 13, 20p.

Fitz -Gibbon, C. (1996). Inspecting her majesty inspectors : Should social science and social policy cohere?, Paper presented at the European Conference On Educational Research, Seville, Spain.

Gather Thurler, M. (1994). L’efficacité des établissements ne se mesure pas : elle se construit, se négocie, se pratique et se vit, [School Effectiveness cannot be measured : it is a matter of process, of negociations, of praxis and of life] in M. Crahay Ed. Evaluation et analyse des établissements de formation, pp. 203-224, Louvain : de Boeck.

Grisay, A. (1997). Evolution des acquis cognitifs et socio affectifs des élèves au cours des années de collège, [How cognitive and non-cognitive skills develop during the middle school years] Les dossiers Education et Formation, 88, MEN-DEP : Paris.

Knuver, A.W.M. \& Bransdma,H.P. (1993). Cognitive and affective outcomes in school effetiveness research, School Effectiveness and School Improvement, 4(3). 
Lepage, C. (2000). L'autonomie des établissements et l'assouplissement de la carte scolaire, enquête exploratoire, [Autonomy of the schools and enhancement of the flexibility of the zoning procedure : a preliminary inquiry] Université de Bourgogne-Iredu, multigr., 85p.

MacBeath, J.(1999). Schools must speak for themselves, The case for school evaluation, London: Routledge.

MacBeath, J., Jakobsen, L.B., Meuret, D., Schratz, M. (1998). Evaluating school quality and performance in 18 countries, Paper presented at the AERA congress, San Diego.

MacBeath, J., Meuret, D., Schratz, M., Jakobsen, L.B. (1999). Evaluation quality in school education, Final report, Brussels: European Commission.

MacBeath, J., Schratz, M., Meuret, D., Jakobsen, L.B (2000). Self-evaluation in European Schools, London : Routledge.

Meuret, D.(1987). Le tableau de bord des collèges et des lycées : histoire d’un ajustement, [Some Indicators for middle and high schools : the story of an adjustment]Politiques et Management Public, 4, 1-28.

Meuret, D.(1992). Pourquoi faut-il mesurer ce qui peut l'être du fonctionnement des établissements scolaires, [Why should we measure what can be measured from the school process ? ] Paris : MEN-DEP.

Meuret,D. \& Marivain, T. (1997). Inégalités de bien être au collège, [Inequalities of well being in middle schools ]Les dossiers Education et Formation, 88, 106p., Paris : MEN-DEP.

Milgrom, P. \& Roberts, J., (1992). Economics, organisation and management, Englewood cliff : Simon\& Shuster, Prentice Hall.

Niskanen, W.J. (1971.) Bureaucracy and Representative Government, Chicago: Aldine Atherton.

Opdenakker, M.C. \& Van Damme,J. (2000). Effects of schools and classes on achievement and well being in secondary education: Similarities and differences between school outcomes, School Effectiveness and School Improvement, 11.

Sammons, P., Hillman, J. \& Mortimore, P.(1995). Key characteristics of effective schools: A review of school effectiveness research, London : Office for standards in Education.

Saunders L.(1999) Who or what is self-evaluation for? School Effectiveness and School Improvement, 10, 414-430. 
Scheerens, J.(1997). Conceptual models and theory embedded principles on effective schooling, School Effectiveness and School Improvement, 8 , 269-310.

Simmons, H. (1988) L'évaluation et la réforme des établissements scolaires, [School evaluation and school reform]A report for the Council of Europe, $\mathrm{n}^{\circ} 18-777$

European Commission (1999), Evaluating quality in school education, Finnish report, Brussels: European Commission.

OECD (1998) Education at a Glance, Paris : OECD. 